\title{
Penerapan Pembelajaran Kooperatif Model Think-Pair-Square (TPS) Untuk Meningkatkan Aktivitas dan Prestasi Belajar Siswa Kelas VIIID Semester II SMP Negeri 20 Malang
}

\author{
Desis Silviriyanti \\ Universitas Negeri Malang
}

\begin{abstract}
Abstrak
Berdasarkan hasil observasi dan wawancara dengan guru IPA (fisika) kelas VIII $_{D}$ semester II SMP Negeri 20 Malang diperoleh informasi bahwa pembelajaran yang digunakan masih didominasi oleh guru dan kadang menggunakan diskusi. Namun diskusi yang digunakan tidak membuat siswa menjadi aktif, karena siswa lebih senang memilih sendiri kelompok diskusinya. Situasi tersebut membuat proses belajar mengajar kurang efektif dan maksimal, sehingga prestasi belajar siswa menjadi kurang maksimal. Salah satu model pembelajaran yang dapat diterapkan untuk membuat siswa lebih aktif adalah model pembelajaran TPS. Jenis penelitian yang digunakan adalah Penelitian Tindakan Kelas (PTK) yang dilaksanakan dalam 2 siklus. Bentuk tindakan pada siklus I merupakan perbaikan untuk tindakan pada siklus II. Tindakan yang diberikan adalah penerapan model pembelajaran TPS. Penerapan pembelajaran ini terlaksana dengan baik. Hal ini dapat ditunjukkan pada tahap berfikir, berpasangan dan berempat di siklus I yang belum terlaksana dengan baik dan lancar menjadi lebih baik pada siklus II. Aktivitas belajar siswa mengalami peningkatan dari siklus I ke siklus II pada kategori baik dengan persentase rata-rata aktivitas siswa pada siklus I sebesar 7\% untuk kategori K (Kurang); 54\% untuk tingkat C (Cukup) dan 39\% pada kategori B (Baik), mengalami peningkatan ke kategori baik ditandai dengan berkurangnya jumlah siswa yang mencapai kategori $K$ dan $C$, yaitu rata-rata aktivitas siswa pada siklus II sebesar 0\% untuk kategori K (Kurang); 46,5\% untuk kategori C (Cukup) dan 53,5\% pada kategori B (Baik). Prestasi belajar mengalami peningkatan dari siklus I ke siklus II, ditandai oleh peningkatan skor tes tulis rata-rata siswa sebesar 6,95 (9,55\%) dan peningkatan persentase ketuntasan belajar sebesar 45\% dari 40\% menjadi $85 \%$.
\end{abstract}

Kata kunci: model TPS, aktivitas belajar, prestasi belajar

\section{PENDAHULUAN}

Pencapaian observasi dan wawancara dengan guru IPA (fisika) di SMP Negeri 20 Malang kelas VIIID diperoleh informasi tentang kurikulum yang digunakan adalah Kurikulum Tingkat Satuan Pendidikan (KTSP). Situasi kelas dan metode pembelajaran yang digu-nakan di kelas masih didominasi oleh guru. Hal ini berakibat aktivitas belajar siswa masih sangatlah rendah, sehingga menyebabkan siswa merasa bosan, mengantuk, bermain sendiri, berbicara hal-hal di luar materi pelajaran dengan teman sebangkunya, tidak memperhatikan penjelasan yang disampaikan oleh guru dan kemauan siswa untuk belajar masih kurang. Dampak lain dari yang tersebut di atas adalah kurangnya 
kemandirian siswa, yang dapat membuat guru sangat sulit untuk membangkitkan aktivitas belajar siswa. Peran utama yang berada di tangan guru ini menyebabkan guru hanya menyampaikan semua informasi dan pengetahuan yang dia miliki kepada siswa, sehingga menyebabkan guru kurang optimal dalam melakukan interaksi langsung dengan siswanya. Guru masih jarang melakukan tanya jawab dan percobaan, sedangkan siswa hanya mendengarkan, mencatat materi yang disam-paikan oleh guru, jarang yang bertanya dan menanggapi pertanyaan guru. Bahkan siswa yang berada di belakang tidak mencatat saat ada materi yang seharusnya di catat. Diskusi kelas dan diskusi kelompok jarang dilaksanakan. Siswa lebih senang membuat kelompok dalam diskusi dengan mereka yang memilih sendiri anggota-anggota kelompoknya. Diskusi kelas dan kelompok yang seperti ini tidak membuat siswa menjadi aktif, begitu juga diskusi kelompok tidak membuat siswa maksimal dalam menerima pelajaran karena dalam pembentukan kelompok pada diskusi kelas tidak berdasarkan pertimbangan kemampuan akade-mik siswa. Situasi yang demikian dapat dikatakan bahwa proses belajar mengajar IPA (fisika) kurang efektif dan maksimal.

Menurut Lie (2002:30) banyak penelitian menunjukkan bahwa pengajaran oleh rekan sebaya (peer teaching) ternyata lebih efektif daripada pengajaran berpusat pada guru. Hal ini disebabkan oleh latar belakang penga-laman dan pengetahuan para siswa yang lebih mirip satu dengan yang lainnya. Model pembelajaran TPS yang setiap tahapannya lebih mengutamakan partisipasi siswa untuk mendapatkan pengetahuan, sehingga siswa tidak akan merasa takut, gelisah, dan kurang percaya diri dalam menjawab dan menyelesaikan masalah yang diberikan, karena mereka belajar dan berbagi pengetahuan dengan teman sebayanya. Salah satu model pembelajaran kooperatif yang dapat meningkatkan aktivitas belajar siswa adalah TPS. Masalah yang akan dipecahkan dalam penelitian ini adalah sebagai berikut. (1) Bagaimana keterlaksanaan pembelajaran kooperatif model TPS pada kelas VIIID semester II SMP Negeri 20 Malang, (2) Apakah penerapan pembelajaran kooperatif model TPS dapat meningkatkan aktivitas belajar siswa kelas VIIID semester II SMP Negeri 20 Malang, (3) Apakah penerapan pembelajaran kooperatif model TPS dapat meningkatkan prestasi belajar siswa kelas VIIID semester II SMP Negeri 20 Malang?

\section{KAJIAN PUSTAKA}

\section{Pembelajaran Kooperatif}

Pembelajaran kooperatif merupakan suatu model pengajaran dimana siswa belajar dalam kelompok-kelompok kecil 
yang memiliki tingkat kemampuan berbeda. Setiap anggota saling bekerja sama dan membantu untuk memahami suatu bahan pembelajaran dalam menyelesaikan tugas kelompok. Belajar belum selesai jika salah satu teman dalam kelompok belum menguasai bahan pembelajaran. Hal ini sejalan dengan Isjoni (2007:21) tujuan utama dalam penerapan model belajar mengajar kooperatif adalah agar siswa dapat belajar secara berkelompok bersama teman-temannya dengan cara saling menghargai pendapat dan memberikan kesempatan kepada orang lain untuk mengemukakan gagasannya dengan menyampaikan pendapat mereka secara berkelompok.

Model pembelajaran kooperatif dikembangkan untuk mencapai hasil belajar akademik dan keterampilan sosial siswa. Salah satu tujuan pembelajaran kooperatif adalah untuk mengajarkan kepada siswa keterampilan kerjasama dan kolaborasi (Wartono,2005:8). Model pembelajaran kooperatif telah terbukti dapat dipergunakan dalam berbagai mata pelajaran dan berbagai usia (Isjoni, 2007:16).

\section{Model pembelajaran TPS}

Menurut Isjoni (2007:78) Think-PairSquare dikembangkan oleh Spencer Kagan. Model pembelajaran ini merupakan pengembangan dari Think-Pair-Share yang dikembangkan oleh Frank Lyman. Tehnik ini memberi siswa kesempatan untuk bekerja sendiri serta bekerja sama dengan orang lain. Teknik ini bisa digunakan dalam semua mata pelajaran dan untuk semua tingkatan usia anak didik.

Teknik berpikir-berpasanganberempat ini memberikan kesempatan sedikitnya delapan kali lebih banyak kepada setiap siswa untuk dikenali dan menunjukkan partisipasi mereka kepada orang lain. Langkah-langkah model pembelajaran Think-Pair-Square menurut Lie (2002:56-57) adalah sebagai berikut.

a. Guru membagi siswa dalam kelompok berempat dan memberikan tugas kepada semua kelompok.

b. Setiap siswa memikirkan dan mengerjakan tugas tersebut sendiri.

c. Siswa berpasangan dengan salah satu rekan dalam kelompok dan berdiskusi dengan pasangannya.

d. Kedua pasangan bertemu kembali dalam kelompok berempat. Siswa mempunyai kesempatan untuk membagikan hasil kerjanya kepada kelompok berempat.

\section{Aktivitas Belajar}

Menurut Lie (2002:30) untuk mencapai hasil yang maksimal, terdapat lima unsur model pembelajaran gotong royong atau kooperatif yang harus diterapkan yaitu sebagai berikut:

1. Saling ketergantungan positif 
Keberhasilan kelompok sangat tergantung pada usaha setiap anggotanya. Setiap anggota ini bekerja demi tercapainya satu tujuan yang sama. Setiap anggota akan merasa bertanggung jawab untuk menyelesaikan tugasnya agar yang lain bisa berhasil. Setiap siswa mendapatkan nilainya sendiri dan nilai kelompok.

2. Tanggung jawab perseorangan

Setiap siswa akan merasa bertanggung jawab untuk melakukan yang terbaik sehingga masing-masing anggota kelompok harus melaksanakan tanggung jawabnya sendiri agar tugas selanjutnya dalam kelompok bisa dilaksanakan.

3. Tatap muka

Setiap kelompok harus diberikan kesempatan untuk bertemu muka dan berdiskusi. Hasil pemikiran beberapa kepala akan lebih kaya daripada hasil pemikiran sari satu kepala saja.

4. Komunikasi antar anggota

Seorang guru perlu membekali siswa mengenai keterampilan berkomunikasi. Siswa diberi motivasi untuk menggunakan keterampilan berinteraksi dan berkomunikasi secara benar dan efektif dalam kelompoknya.

5. Evaluasi proses kelompok

Seorang guru perlu menjadwalkan waktu khusus bagi kelompok untuk mengevaluasi proses kerja kelompok dan hasil kerja sama mereka agar selan-jutnya bisa bekerja sama dengan lebih efektif.

\section{Prestasi Belajar}

Salah satu cara untuk mengetaui prestasi belajar siswa dapat dilakukan dengan menggunakan penilain tes. Menurut Sudijono (dalam Djaali, 2004:8) Tes merupakan alat atau prosedur yang dipergunakan dalam rangka pengukuran dan penilaian. Menurut taksonomi Bloom (dalam Winkel, 1989:149) Rana koginif (cognitif domain) meliputi:

Pengetahuan (knowledge), mencakup ingatan akan hal-hal yang pernah dipelajari dan disimpan dalam ingatan.

Pemahaman (comprehension), mencakup kemampuan untuk menangkap makna dan arti dari bahan yang dipelajari. Adanya kemampuan ini dinyatakan dalam menguraikan isi pokok dari suatu bacaan, mengubah data yang disampaikan dalam bentuk tertentu ke bentuk yang lain. (3) Penerapan (application), mencakup kemampuan untuk menerapkan suatu kaidah atau metode bekerja pada suatu kasus atau problem yang konkret dan baru.

(4) Analisis (analysis), mencakup kemampuan untuk merinci suatu kesatuan ke dalam bagian-bagian, sehingga struktur keseluruhan atau organisasinya dapat dipahami dengan baik. Adanya kemampuan ini dinyatakan dalam penganalisaan bagian- 
bagian pokok atau komponen-komponen dasar, bersama dengan hubungan atau relasi antara bagian-bagian itu. (5) Sintesis (synthesis), mencakup kemampuan untuk membentuk suatu kesatuan atau pola baru. (6) Evaluasi (evaluation), mencakup kemampuan untuk membentuk suatu pendapat mengenai sesuatu atau beberapa hal, bersama dengan pertanggungjawaban pendapat itu, yang berdasarkan kriteria tertentu. Kemampuan ini dinyatakan dalam memberikan penilaian terhadap sesuatu.

\section{METODE PENELITIAN}

Penelitian ini menggunakan pendekatan kualitatif dan jenis penelitian ini adalah penelitian tindakan kelas (PTK) dengan memberikan tindakan berupa pembelajaran kooperatif model TPS. Subjek penelitiannya adalah siswa kelas VIIID semester II SMP Negeri 20 Malang tahun ajaran 2009/2010 yang berjumlah 40 siswa yang terdiri dari 17 siswa laki-laki dan 23 siswa perempuan.

Tahapan penelitian dilakukan dengan menggunakan siklus yang terdiri dari perencanaan, tindakan, observasi, evaluasi dan refleksi. Penelitian tindakan kelas dilaksanakan dalam 2 siklus. Bentuk tindakan pada siklus I merupakan perbaikan untuk tindakan pada siklus II. Instrumen penelitian yang digunakan yaitu lembar observasi keterlaksanaan pembelajaran, lembar aktivitas belajar siswa dan tes tulis.
Data dalam penelitian ini bersifat kualitatif. Analisis data pada penelitian ini meliputi: (a) Reduksi data adalah proses penyederhanaan yang dilakukan melalui seleksi pemfokusan dan pengabstraksian data mentah menjadi informasi yang bermakna. (b) Penyajian data, data yang sudah diklasifikasikan dan disederhanakan, dideskripsikan dalam bentuk kata-kata yang bermakna, dan (c) Penarikan kesimpulan adalah pengambilan intisari dari sajian data yang berupa kalimat singkat padat tetapi mengandung pengertian luas yang mewakili keseluruhan. Data penelitian ini dikumpulkan dengan tiga cara yakni tes tulis bentuk pilihan ganda (untuk prestasi belajar), lembar observasi aspek aktivitas belajar, dan lembar observasi keterlaksanaan pembelajaran. Keterlaksanaan model pembelajaran bersifat kualitatif. Sedangkan prestasi belajar dan kerja ilmiah kuantitatif (berupa angka).

\section{HASIL DAN PEMBAHASAN \\ Paparan Data}

Proses pengumpulan dan analisis data, maka diperoleh hasil penelitian. Hasil penelitian ini akan disajikan dalam bentuk kolom ringkas yang berisi tentang semua informasi dari hasil observasi. Kolom ringkas laporan berikut ini merupakan jawaban dari masalah yang sudah dirumuskan pada bab sebelumnya. Data Keterlaksanaan pembelajaran dengan model TPS pada Siklus I dan Siklus II 
Siklus I

\begin{tabular}{|c|c|c|c|}
\hline No & $\begin{array}{l}\text { Tahap } \\
\text { Pembelajaran }\end{array}$ & Kelemahan & Kemungkinan Solusi \\
\hline 1 & $\begin{array}{l}\text { Berfikir } \\
\text { (think) }\end{array}$ & $\begin{array}{l}\text { Guru melewatkan langkah melakukan } \\
\text { demonstrasi dengan bantuan siswa. 'Pada } \\
\text { awal pembelajaran guru lupa melakukan } \\
\text { demonstrasi mengenai bandul sederhana yang } \\
\text { tujuannya untuk mengarahkan siswa untuk } \\
\text { memahami pengertian getaran dan } \\
\text { mengetahui yang dinamakan satu getaran'. }\end{array}$ & $\begin{array}{l}\text { Guru memastikan tiap } \\
\text { langkah yang akan } \\
\text { dilaksanakan sesuai dengan } \\
\text { rencana pelaksanaan } \\
\text { pembelajaran yang telah } \\
\text { dibuat. Apabila perlu RPP } \\
\text { dipegang terus. }\end{array}$ \\
\hline 2 & $\begin{array}{l}\text { Berempat } \\
\text { (square) }\end{array}$ & $\begin{array}{l}\text { Siswa banyak yang protes dan merasa tidak } \\
\text { cocok dengan teman dalam kelompoknya, } \\
\text { sehingga siswa tidak segera berkumpul } \\
\text { dengan kelompoknya. 'Di sini siswa banyak } \\
\text { yang protes karena tidak cocok dengan teman } \\
\text { dalam kelompoknya, dan pada waktu } \\
\text { perpindahan tempat duduk siswa masih } \\
\text { terlihat malas dan lambat berpindah yang } \\
\text { mengakibatkan terbuangnya waktu } \\
\text { pembelajaran, tetapi guru segera bisa } \\
\text { menguasai kelas dengan menegaskan untuk } \\
\text { tetap berkelompok sesuai pembagian yang } \\
\text { telah di buat guru'. }\end{array}$ & $\begin{array}{l}\text { Guru terlebih dahulu } \\
\text { memberikan pengertian dan } \\
\text { penjelasan bahwa dalam } \\
\text { pembentukan kelompok } \\
\text { belajar dapat menentukan } \\
\text { keberhasilan proses belajar, } \\
\text { sehingga pembentukan } \\
\text { kelompok yang tepat akan } \\
\text { membuat berhasilnya } \\
\text { proses belajar kelompok. }\end{array}$ \\
\hline 3 & $\begin{array}{l}\text { Berempat } \\
\text { (square) }\end{array}$ & $\begin{array}{l}\text { Kelas terlihat penuh dan sesak, sehingga } \\
\text { sedikit mengganggu kegiatan belajar. } \\
\text { 'Ternyata dengan berkelompok berempat ini, } \\
\text { kelas terkesan menjadi penuh dan sempit'. }\end{array}$ & $\begin{array}{l}\text { Menggunakan ruang } \\
\text { laboratutium yang ruangnya } \\
\text { lebih luas dan penataan } \\
\text { tempat yang } \\
\text { memungkinkan dan cocok } \\
\text { apabila digunakan untuk } \\
\text { belajar secara berkelompok. }\end{array}$ \\
\hline 4 & $\begin{array}{l}\text { Berempat } \\
\text { (square) }\end{array}$ & $\begin{array}{l}\text { Masih banyak siswa yang bingung } \\
\text { melakukan percobaan. Hal ini disebabkan } \\
\text { siswa belum membaca langkah kerja } \\
\text { percobaan yang seharusnya sudah dibaca dan } \\
\text { dipahami sebelumnya. 'Pada awalnya hampir } \\
\text { semua kelompok yang masih belum mengerti } \\
\text { bagaimana cara melakukan praktikum } \\
\text { tersebut'. }\end{array}$ & $\begin{array}{l}\text { Guru memberikan petunjuk } \\
\text { tegas agar terlebih dahulu } \\
\text { membaca dan memahami } \\
\text { langkah kerja percobaan } \\
\text { sehingga siswa tidak akan } \\
\text { kebingungan dalam } \\
\text { melakukan percobaan. }\end{array}$ \\
\hline 5 & $\begin{array}{l}\text { Awal } \\
\text { pembelajaran }\end{array}$ & $\begin{array}{l}\text { Siswa banyak yang belum berada di kelas dan } \\
\text { siap menerima pelajaran, hal ini } \\
\text { mengakibatkan tersitanya waktu } \\
\text { pembelajaran. Keadaan seperti ini disebabkan } \\
\text { sebelum pembelajaran merupakan waktu } \\
\text { istirahat, sehingga siswa santai dan berleha- } \\
\text { leha memperpanjang waktu istirahat. 'Setelah } \\
\text { siswa lengkap berada di dalam kelas guru } \\
\text { memberikan nasehat agar pada saat bel } \\
\text { pelajaran berbunyi siswa harus segera masuk } \\
\text { ke dalam kelas, agar jam pelajaran mereka } \\
\text { tidak tersita karena materi yang akan } \\
\text { disampaikan juga masih banyak. }\end{array}$ & $\begin{array}{l}\text { Guru seharusnya bertindak } \\
\text { tegas dan menasehati siswa } \\
\text { agar segera berada dan siap } \\
\text { menerima pelajaran saat } \\
\text { jam pelajaran dimulai. }\end{array}$ \\
\hline
\end{tabular}


Berdasarkan pelaksanaan tindakan dan observasi siklus II, diperoleh sebagai berikut. Penerapkan model pembelajaran TPS membuat siswa lebih berse-mangat dan aktif dalam proses belajar mengajar IPA (fisika). Keterlaksanaan model pembelajaran TPS yang memiliki empat tahapan pembelajaran, yaitu berfikir (think), berpasangan (pair), berempat (square), dan berbagi dalam kelas telah terlaksana semua.

\section{Data Aktivitas Belajar Siswa pada Siklus I dan Siklus II}

\begin{tabular}{|c|c|c|c|c|c|c|}
\hline \multirow[t]{4}{*}{ Unsur yang diamati } & \multicolumn{5}{|c|}{ Tingkat Ketercapaian (\%) } & \\
\hline & \multicolumn{2}{|c|}{ Kurang } & \multicolumn{2}{|l|}{ Cukup } & \multicolumn{2}{|l|}{ Baik } \\
\hline & Siklus & Siklus & Siklus & Siklus & Siklus & Siklus \\
\hline & $\mathrm{I}$ & II & I & II & I & II \\
\hline 1. Tatap muka & 2,5 & - & 22,5 & 17,5 & 75 & 82,5 \\
\hline 2. Tanggung jawab & 5 & - & 85 & 52,5 & 10 & 47,5 \\
\hline individu & 17,5 & - & 40 & 50 & 42,5 & 50 \\
\hline \multicolumn{7}{|l|}{ 3. Saling Ketergantungan } \\
\hline positif & 10 & - & 40 & 44,5 & 50 & 55,5 \\
\hline $\begin{array}{l}\text { 4. Komunikasi antar } \\
\text { anggota }\end{array}$ & - & - & 82,5 & 57,5 & 17,5 & 42,5 \\
\hline Evaluasi proses & & & & & & \\
\hline \multicolumn{7}{|l|}{ kelompok } \\
\hline Rata-rata & 7 & - & 54 & 46,5 & 39 & 53,5 \\
\hline
\end{tabular}

Data Nilai Tes Tulis Rata-Rata pada Observasi Awal, Siklus I, dan Siklus II

Nilai Tes Tulis Rata-

\begin{tabular}{llll} 
Tes & rata & Kenaikan & Persentase (\%) Kenaikan \\
\hline Observasi & & & \\
Awal & 59,63 & & \\
Siklus I & 72,75 & 13,12 & 22
\end{tabular}


Siklus II

79,70

6,95

9,55

Data Persentase Ketuntasan Belajar Siswa Sebelum Tindakan, Siklus I, dan Siklus II

\begin{tabular}{llll}
\hline Skor & $\begin{array}{l}\text { Sebelum } \\
\text { Tindakan }\end{array}$ & Siklus I & Siklus II \\
& 4 siswa $(10 \%)$ & 16 siswa $(40 \%)$ & 34 siswa $(85 \%)$ \\
\hline$\geq 72$ (tuntas) & 36 siswa $(90 \%)$ & 24 siswa $(60 \%)$ & 6 siswa $(15 \%)$ \\
\hline 71 (belum tuntas) & & \\
\hline
\end{tabular}

\section{Pembahasan}

\section{Keterlaksanaan Model Pembelajaran TPS}

Kegiatan pembelajaran siklus I belum terlaksana sesuai rencana, masih ada tahapan yang belum terlaksana secara maksimal. Demonstrasi mengenai bandul sederhana untuk mengawali tahap berfikir (think) belum terlaksana, karena terlupakan oleh guru, sehingga membuat siswa bingung, alur penyampaian materi menjadi tidak urut, dan berkurangnya aktivitas siswa dalam kelas. Pada tahap berpasangan (pair), beberapa siswa masih terlihat berusaha melihat jawaban pasangan lain dan belum bisa mengoptimalkan waktu yang diberikan guru. Pada tahap berempat (square) saat berdiskusi siswa belum bisa memanfaatkan waktu yang diberikan dengan baik dan tepat. Hal ini disebabkan guru kurang tegas agar siswa melakukan percobaan sesuai dengan langkah kerja yang sudah ada di LKS, sehingga pada pelaksanaan percobaan banyak siswa yang masih kebingungan dalam mela-kukan percobaan. Belum maksimalnya pelaksanaan pembelajaran pada siklus I ini, mungkin juga disebabkan karena siswa baru mengenal dan mengetahui cara belajar dengan model ini, sehingga mereka membutuhkan adaptasi terlebih dahulu.

Proses pelaksanaan siklus II yang secara umum sudah baik dan sesuai dengan rencana pelaksanaan pembelajaran yang dibuat. Pada siklus II untuk tahap berfikir (Think) terlaksana semua dengan baik, hal ini karena guru sudah mengambil pengalaman berharga dari siklus I, sehingga pada siklus II ini guru sudah tidak melakukan lagi langkah-langkah pembelajaran. Tahap berpasangan (Pair) pada siklus II guru telah terlaksana keseluruhan dengan baik. Guru mampu membuat siswa berinteraksi, berkomunikasi dan belajar dalam bentuk berpasangan. Siswa berkomunikasi dengan pasangannya untuk memecahkan dan mencocokkan jawaban masalah yang sebelumnya sudah mereka pikirkan sendiri. 
Tahap berempat juga terlaksana semua dengan baik, guru telah bisa tegas pada siswa agar sebelum percobaan seharusnya memahami dahulu langkah kerja, sehingga tidak akan kesulitan pada saat melakukan percobaan. Tahap berbagi dengan kelas pada siklus II seluruhnya terlaksana. Siswa sudah bisa melakukan presentasi, diskusi, dan juga penyimpulan diskusi dengan baik, walaupun pada siklus I siswa masih terkesan malu dan ragu-ragu namun pada siklus II siswa sudah bisa melakukannya dengan baik dan lancar. Tes yang dilakukan pada siklus I dan II berjalan dengan baik. Penghargaan kelompok dilakukan setelah selesai melakukan tes. Penghargaan kelompok ini dimaksudkan untuk memberi semangat dan lebih memacu untuk bersungguh-sungguh dalam pembelajaran. Kelompok dengan nilai rata-rata tertinggi yang mendapatkan penghargaan. Penghargaan yang diberikan di sini berupa alat tulis, sehingga dapat bermanfaat juga untuk siswa.

Penerapan Pembelajaran Kooperatif Model TPS terhadap Aktivitas Belajar

\section{Siswa}

Aspek tatap muka dari siklus I ke siklus II mengalami peningkatan pada kategori baik, yaitu sebesar 7,5\% sedangkan untuk kategori kurang dan cukup, aspek tatap muka mengalami penurunan masing-masing sebesar 2,5\% dan 5\%. Penurunan ini menunjukkan bahwa pada saat diskusi dan percobaan siswa segera mencari dan berkumpul dengan anggotanya serta siswa sudah duduk berhadapan saat diskusi. Aspek tanggung jawab individu dari siklus I ke siklus II mengalami peningkatan pada kategori baik yaitu sebesar 37,5\%, sedangkan pada kategori kurang dan cukup, aspek tanggung jawab individu mengalami penurunan masing-masing sebesar 5\% dan $32,5 \%$. Penurunan ini menunjukkan bahwa siswa sudah mengerjakan LKS dan siswa dapat menjelaskan kepada kelompoknya tentang materi yang menjadi tugasnya. Aspek saling ketergantungan positif dari siklus I ke siklus II mengalami peningkatan pada kategori baik dan cukup masingmasing sebesar $7,5 \%$ dan $10 \%$, sedangkan untuk kategori kurang mengalami penurunan sebesar $17,5 \%$. Penurunan pada kategori tersebut menunjukkan bahwa siswa sudah bisa bertanggung jawab untuk menyelesaikan tugas yang diberikan kepadanya, aktif bertanya, dan memberikan pendapatnya saat diskusi. Aspek komunikasi antar anggota dari siklus I ke siklus II mengalami peningkatan pada kategori baik dan cukup masing-masing sebesar 5,5\% dan 4,5\%, sedangkan pada kategori kurang mengalami penurunan sebesar 10\%. Hal ini menunjukkan bahwa siswa sudah mengajukan pendapat, mengajukan pertanyaan dengan jelas, dan mau mendengarkan penjelasan anggota 
kelompoknya pada saat diskusi. Aspek evaluasi proses kelompok mengalami peningkatan pada kategori baik, yaitu sebesar 25\% sedangkan pada kategori kurang tidak mengalami pening-katan ataupun kenaikan (tetap), dan pada kategori cukup mengalami penurunan sebesar $25 \%$. Hal ini menunjukkan bahwa siswa berpartisipasi dalam kerja kelom-pok, tepat waktu dalam menyelesaikan tugas yang diberikan kepadanya, dan mampu membuat kesimpulan berdasarkan tujuan diskusi.

Berdasarkan pembahasan yang telah dipaparkan di atas, penggunaan metode pembelajaran kooperatif TPS dapat meningkatkan aktivitas belajar siswa. Hal ini dapat dilihat dari aktivitas belajar siswa dari siklus I ke siklus II yang mengalami kenaikan pada kategori baik, walaupun kenaikan yang terjadi tidak besar. Selanjutnya apabila model pembelajaran TPS terus diterapkan di kelas VIIID semester II SMP Negeri 20 Malang, kemungkinan aktivitas belajar siswa akan lebih meningkat lagi.

\section{Penerapan Pembelajaran Kooperatif}

Model TPS terhadap Prestasi Belajar

\section{Siswa}

Prestasi belajar siswa dapat dilihat dari nilai tes tulis rata-rata dan persen-tase ketuntasan belajar siswa. Nilai tes tulis ratarata siswa dari tes pada observasi awal, dan siklus I masing-masing sebesar 59,63 dan 72,75. Hal ini berarti terjadi peningkatan nilai tes tulis rata-rata sebesar $13,12(22 \%)$. Begitu juga untuk ketun-tasan belajar siswa dari sebelum tindakan ke siklus I mengalami peningkatan, yaitu dari $10 \%$ menjadi $40 \%$, hal ini berarti terjadi peningkatan sebesar $30 \%$. Peningkatan yang terjadi disebabkan siswa yang biasanya belajar dengan menggunakan metode ceramah dan guru yang menjadi peran utama berganti menjadi pembelajaran yang mengusahakan agar siswa menjadi lebih aktif, sehingga siswa akan lebih memahami materi yang akan diajarkan. Siswa dapat memahami materi karena pada awalnya siswa yang memikirkan dan mencari jawaban dari permasalahan yang diberikan guru dimana permasalahanpermasalahan yang dibe-rikan guru tersebut bersangkutan dengan materi yang akan dipelajari siswa pada hari tersebut. Nilai tes tulis rata-rata siswa dari tes pada siklus I dan siklus II masing-masing sebesar 72,75 dan 79,70. Hal ini berarti terjadi peningkatan nilai tes tulis rata-rata sebesar 6,95 (9,55\%). Peningkatan juga terjadi pada ketuntasan belajar dari siklus I ke siklus II, yaitu sebagai berikut: dari $40 \%$ (siklus I) menjadi $85 \%$ (siklus II), berarti terjadi peningkatan ketuntasan belajar siswa ini sebesar $45 \%$, peningkatan ini lebih baik dari sebelumnya yang hanya $30 \%$. Peningkatan yang lebih baik ini disebabkan pada siklus II siswa sudah mengerti dan mulai terbiasa dengan penerapan model 
pembelajaran TPS yang diterapkan, sehingga siswa dapat belajar dengan maksimal.

Berdasarkan uraian di atas yang menyatakan bahwa mulai sebelum tindakan ke siklus I sampai dengan ke siklus II yang terus mengalami peningkatan, selanjutnya apabila model TPS terus diterapkan, kemungkinan prestasi belajar siswa akan lebih meningkat lagi.

\section{SIMPULAN}

Penerapan pembelajaran dengan model pembelajaran TPS melalui empat tahapan meliputi berfikir (think), berpasangan (pair), berempat (square), dan berbagi dalam kelas, terlaksana dengan baik. Penerapan pembelajaran dengan model pembelajaran TPS dapat meningkatkan aktivitas belajar siswa. Hal ini ditunjukkan dengan persentase rata-rata aktivi-tas siswa pada siklus I sebesar 7\% untuk kategori K (Kurang); 54\% untuk kategori C (Cukup) dan 39\% pada kategori B (Baik), sedangkan pada siklus II mengalami peningkatan ke kategori baik dengan berkurangnya jumlah siswa yang mencapai kategori $\mathrm{K}$ dan $\mathrm{C}$. Persentase rata-rata aktivitas siswa pada siklus II sebesar 0\% untuk kategori K (Kurang); 46,5\% untuk kategori C (Cukup) dan 53,5\% pada kategori B (Baik). Penerapan pembelajaran dengan model pembelajaran TPS dapat meningkatkan prestasi belajar siswa. Hal ini ditunjukkan dari siklus I ke siklus II yang mengalami peningkatan untuk skor tes tulis rata-rata siswa sebesar $6,95(9,55 \%)$ dan peningkatan persentase ketuntasan belajar sebesar $45 \%$ dari $40 \%$ menjadi $85 \%$.

\section{DAFTAR PUSTAKA}

Arikunto, S. 2003. Dasar-Dasar Evaluasi Pendidikan. Jakarta: PT. Bumi Aksara.

Arikunto, S. 2006. Prosedur Penelitian Edisi Revisi VI. Jakarta: PT. Rineka Cipta.

Dasna, I. \& Fatchan, A. 2008. Penelitian Tindakan Kelas \& Penulisan Karya Ilmiah. Malang: Departemen Pendidikan Nasional Universitas Negeri Malang PSG Rayon 15.

Djaali. 2004. Pengukuran Dalam Bidang Pendidikan. Jakarta: Program Pascasarjana Universitas Negeri Jakarta.

Hasibuan. 2003. Kemampuan Dasar Mengajar. Malang: Departemen Pendidikan Nasional Universitas Negeri Malang.

Isjoni. 2007. Cooperative Learning Efektivitas Pembelajaran Kelompok. Bandung: Alfabeta.

Kanginan, Marthen. 2002. IPA Fisika untuk SMP Kelas VIII. Jakarta: Erlangga.

Kartono, Agus. 2008. Seribupena Fisika SMP Kelas VIII. Bandung: Erlanga.

Khalim, Abdul. 2008. Sains Fisika 2 SMP/MTs. Jakarta: Bumi Aksara. 
Khasanah, Uswatun. 2009. Penerapan Pembelajaran Kooperatif Model Two Stay Two Stray (dua tinggal dua tamu) Untuk Meningkatkan Aktivitas Dan Hasil Belajar Siswa Kelas VIII Semester I SMP Negeri 10 Malang. Skripsi tidak diterbitkan. Malang: Universitas Negeri Malang.

Lie, A. 2002. Mempraktekkan Cooperatif Learning Di Ruang-Ruang Kelas. Jakarta: PT. Gramedia.

Majid, A. 2007. Perencanaan Pembelajaran. Bandung: PT. Remaja Rosdakarya.

Moleong, L. J. 2005. Metode Penelitian Kualitatif. Bandung: PT. Remaja Rosdakarya.

Mulyasa, E. 2007. Kurikulum Tingkat Satuan Sekolah. Bandung: PT. Remaja Rosdakarya.

Ningrum, S. 2006. Penerapan Pembelajaran Kontekstual (Contextual Teaching and Leaning) Model Inkuiri dalam Meningkatkan Prestasi Belajar Kemampuan Kerja Ilmiah Siswa Kelas X SMA Laboratorium UM pada Materi Hukum Ohm dan Rangkaian Seri Paralel. Skripsi tidak diterbitkan.
Malang: Universitas Negeri Malang.

Prasodjo, Budi. 2006. Teori dan Aplikasi Fisika SMP Kelas VIII. Bogor: Yudistira

Purwanti, Endang. 2009. IPA TERPADU untuk SMP/MTs. Klaten: Intan Pariwara

Rifa'i, Danang. 2008. Penerapan Pembelajaran Kooperatif Model Think Pair Square Untuk Meningkatkan Hasil Belajar Matematika Siswa Kelas X SMAN 8 Malang. Skripsi tidak diterbitkan. Malang: Universitas Negeri Malang.

Susanti, Eka Fetania. 2010. Pengaruh Pembelajaran Kooperatif Dengan Model Pembelajaran Think Pair Square Terhadap Hasil Belajar Siswa Pada Mata Pelajaran Akuntansi. Skripsi tidak diterbitkan. Malang: Universitas Negeri Malang.

Wartono. 2005. Model-model Pembelajaran Di SMP, MTs, SMA, $M A$. Malang: Universitas Negeri Malang.

Winkel, S. 1989. Psikologi Pengajaran Cetakan ke 2. Jakarta: PT. Gramedia. 